\title{
Geranylgeranyltransferase I Inhibitor
}

National Cancer Institute

\section{Source}

National Cancer Institute. Geranylgeranyltransferase I Inhibitor. NCI Thesaurus. Code C104414.

A substance that inhibits protein geranylgeranyltransferase type 1 (GGT ase-I), with potential antineoplastic activity. GGT ase-I is involved in the posttranslational modification of a number of oncogenic GT Pases, including K-Ras, N-Ras, RhoA, RhoC, Cdc42, RalA, RalB and Rac1. Inhibition of the prenylation of these oncogenic proteins inhibits both their oncogenic activity and membrane localization. This may result in cell cycle arrest and apoptosis. Protein geranylgeranylation, catayzed by GGT ase-I, plays a critical role in malignant transformation and cancer cell proliferation, migration and invasion. 